\title{
SOSIALISASI DAN PEMBAGIAN MASKER GRATIS SEBAGAI UPAYA PREVENTIF/ PENCEGAHAN PENYEBARAN VIRUS COVID-19 DI DESA TEROS KECAMATAN LABUHAN HAJI
}

\author{
Widya Hartati ${ }^{1)}$, Ratna Yuniarti' ${ }^{1)}$, Alpiana ${ }^{2)}$ \\ 1)Program Studi Administrasi Publik, Sekolah Tinggi Ilmu Administrasi Muhammadiyah Selong, NTB, Indonesia \\ 2)Program Studi S1 Tambang, Fakultas Teknik, Universitas Muhammadiyah Mataram, NTB, Indonesia \\ Corresponding author :Widya Hartati \\ E-mail :widyahartaty@gmail.com
}

Diterima 06 November 2021, Direvisi 29 November 2021, Disetujui 29 November 2021

\begin{abstract}
ABSTRAK
Virus covid 19 merupakan kumpulan virus yang menyebabkan infeksi sistem saluran pernapasan. penyebaran virus covid 19 ini semakin meningkat setiap harinya, Melihat penomena yang terjadi di masyarakat maka dirasa sangat perlu dilakukannya kegiatan Sosialisasi dan pembagian masker gratis untuk memutus rantai penyebaran virus covid 19. Tujuan dari kegiatan pengabdian pada masyarakat ini adalah memberikan pengetahuan, pemahaman dan kesadaran kepada warga masyarakat tentang perlunya sosialisasi physical distancing dan penggunaan masker untuk mencegah penyebarab virus covid-19 yang sudah meresahkan. Metode yang digunakan dalam kegiatan ini adalah dengan cara sosialisasi dari rumah ke rumah kemudian membagikan masker gratis kepada warga yang ada di RT 02/RW.04. dengan dilaksanakannya pengabdian tersebut maka warga masyarakat di RT.02/RW.04 merasa lebih paham setelah dilakukannya sosialisasi dan merasa terbantu dengan pembagian masker gratis. Selain itu, hasil yang Diharapkan masyarakat lebih sadar akan pentingnya kesehatan dengan selau menerapkan phsicial distancing dan selalu menggunakan masker ketika berpergian serta menggunakan handsanitaizer ketika sudah melaksanakan kontak dengan warga masyarakat lainnya, sebagai salah satu proteksi atau perlindungan diri dari virus covid 19.
\end{abstract}

Kata kunci: sosialisasi; Virus covid 19; preventif; masker.

\begin{abstract}
The COVID-19 virus is a group of viruses that cause infections of the respiratory system. the spread of the covid 19 virus is increasing every day, Seeing the phenomena that occur in the community, it is felt that it is very necessary to carry out socialization activities and the distribution of free masks to break the chain of spread of the covid 19 virus. The purpose of this community service activity is to provide knowledge, understanding and awareness to the community. community members about the need for social distancing and the use of masks to prevent the spread of the Covid-19 virus which is already troubling. The method used in this activity is by socializing from house to house and then distributing free masks to residents in RT 02/RW.04. With the implementation of this service, the community members in RT.02/RW.04 feel more understanding after the socialization and feel helped by the distribution of free masks. In addition, the expected result is that the public is more aware of the importance of health by always implementing physical distancing and always using a mask when traveling and using a hand sanitizer when in contact with other members of the community, as one of the protections or self-protection from the covid 19 virus.
\end{abstract}

Keywords: socialization; covid 19 virus; prevention; masks.

\section{PENDAHULUAN}

Virus Corona atau biasa disebut dengan virus covid 19 merupakan kumpulan virus yang menyebabkan infeksi saluran pernapasan. Dengan melihat perkembangan penyebaran wabah virus covid-19 yang ada di Indonesia pada umumnya, yang sudah dikategorikan pandemik bahkan virus covid -19 ini sudah bisa meresahkan penduduk dunia karena sudah menyebar ke 200 Negara dengan 662.073 kasus (Muhyiddin, 2020) dengan melihat fenomena sekarang ini diprediksikan kasus penyebaran wabah ini semakin meningkat setiap harinya, bahkan di Indonesia sendiri yang awalnya 1 kasus meningkat menjadi ratusan kasus hal ini bisa dilihat di berita di media elektronik yang setiap hari selalu update jumlah warga yang terjangkit virus 
covid-19 (Parwanto, 2021). Virus ini menular melalui percikan dahak (droplet) dari saluran pernapasan misalnya ketika berada di ruang tertutup yang ramai dengan sirkulasi udara yang kurang baik atau terjadi kontak langsung dengan droplet.

Gejala awal infeksi virus corona atau covid 19 bisa menyerupai gejala flu yaitu demam, filek, batuk kering, sakit tenggorokan dan sakit kepala (Zahrotunnimah, 2020). Setelah itu gejala bisa hilang maupun memberat, penderita dengan gejala yang berat bisa mengalami demam tinggi, batuk berdahak berdarah, sesak nafas dan nyeri dada. Gejalagejala tersebut muncul ketika tubuh bereaksi melawan virus corona.

Maka berdasarkan hal ini diharapkan perlu untuk melakukan suatu kegiatan peduli sesama yaitu dengan melakukan sosialisasi physical distancing dan pembagian masker sebagai upaya pencegahan virus covid-19 di Desa teros kecamatan labuhan haji.

Desa Teros merupakan salah satu desa yang ada di kecamatan Labuhan haji, Kabupaten Lombok Timur, menurut informasi yang diberikan oleh kepala lingkungan bahwa keadaan masyarakat di desa tersebut terutama di RT.02/RW. 04 belum percaya terhadap virus corona, maka masyarakat enggan memakai masker, hal ini jauh berbeda dengan dusun yang lain yang lebih memahami tentang bahaya virus covid 19 tersebut

Melihat fenomena yang terjadi di masyarakat terutama RT02/RW.04 maka dirasa sangat perlu dilakukannya kegiatan Sosialisasi dan pembagian masker gratis di harapkan mampu memutus rantai penyebaran virus covid-19 yang ada di pedesaan karena di desa tersebut para warganya masih merasa acuh dan tidak peduli terhadap virus covid 19 yang dapat membahayakan nyawa mereka. Dan pembagian masker sebagai upaya untuk membantu warga masyarakat untuk mendapatkan masker yang persediaannya semakin langka, bahkan kalaupun ada pasti harganya jauh lebih mahal disbanding sebelum adanya wabah virus covid-19 ini. Jadi Kegiatan pada masyarakat ini merupakan kegiatan peduli terhadap sesama untuk tujuan kebaikan bersama untuk mencapai kehidupan masyarakat aman, tentram, damai dan sejahtera.

Tujuan dari kegiatan pengabdian pada masyarakat ini adalah memberikan pengetahuan, pemahaman dan kesadaran kepada warga masyarakat tentang perlunya sosialisasi physical distancing dan pembagian masker gratis untuk mencegah penyebarab virus covid-19 yang sudah meresahkan.
Manfaat dari kegiatan pengabdian ini adalah diharapkan warga masyarakat mengetahui dan memahami betapa pentingnya keselamatan diri sendiri dan sesama sebagai upaya saling membantu antara sesama dengan sementara tidak berkumpul untuk memutus penyebaran virus covid-19.

\section{METODE}

Mitra dalam kegiatan pengabdian inii adalah warga masyarakat yang ada di RT.02/RW04 Desa Teros, Kecamatan Labuhan haji yang berjumlah 120 orang kondisinya semula sebelum melakukan kegiatan pengabdian masih belum peduli atau mengabaikan adanya virus covid 19 ini. Hal ini dibuktikan dengan kondisi masyarakat yang belum sama sekali menggunakan masker padahal anjuran dari pemerintah sendiri mewajibkan mereka untuk selau taat protokol kesehatan yaitu dengan menggunakan masker. Mekanisme atau metode pelaksanaan kegiatan dalam pengabdian ini adalah terlebih dahulu melakukan observasi ke RT.02/RW.04 setelah mengetahui kondisi yang ada di masyarakat maka dilanjutkan dengan persiapan alat dan bahan, dan kami berkoordinasi juga dengan kepala lingkungan dalam rangka pelaksanaan kegiatan tersebut. selanjutnya memberikan sosialisasi tentang physical distancing terhadap warga RT.02/RW.04 dengan mendatangi rumah warga desa secara langsung dari rumah ke rumah, hal ini kita laksanakan karena berhubungan dengan tidak mengumpulkan massa dalam jumlah yang banyak hal ini tidak lain untuk mencegah penyebaran virus covid 19 yang semakin meresahkan masyarakat dan negara. Selain memberikan sosialisasi pentingnya penggunaan masker, dalam pengabdian pada masyarakat ini juga melakukan pembagian masker gratis kepada warga masyarakat. Selanjutnya setelah dilaksanakan kegiatan dilanjutkan dengan evaluasi kegiatan. Adapun tahapan kegiatan dapat dilihat pada gambar 1 . 


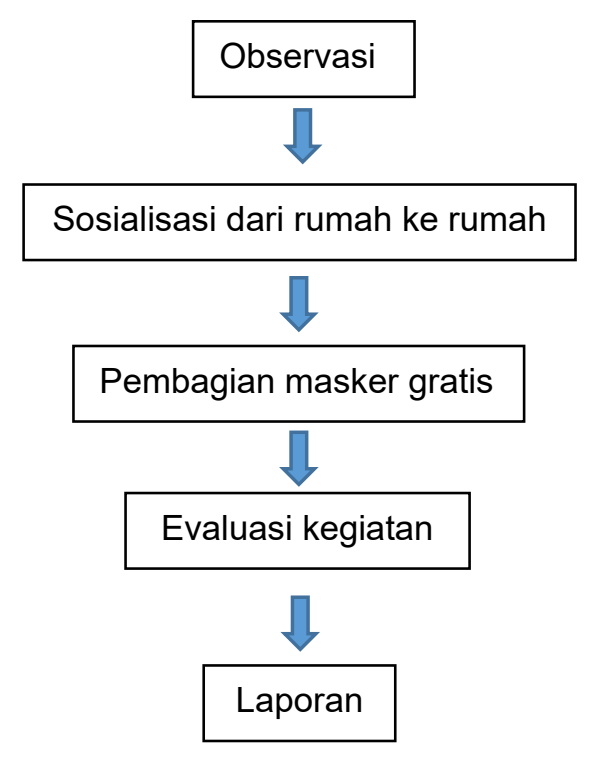

Gambar 1. Tahapan Pelaksanaan Kegiatan

\begin{abstract}
Waktu dan tempat pelaksanaan
Waktu Pelaksanaan kegiatan pengabdian pada masyarakat ini dilakukan tanggal 1-8 April 2021. Tempat Kegiatan ini dilaksanakan di RT.02/RW.04 Desa Teros Kecamatan Labuhan Haji. Peserta Warga masyarakat RT.02/RW.04 Desa Teros Kecamatan Labuhan Haji.
\end{abstract}

\section{HASIL DAN PEMBAHASAN}

Kegiatan pengabdian ini dilaksanakan tanggal 1-8 April di RT 02/RW 04 Desa Teros Kecamatan Labuhan Haji. Kegiatan ini di ikuti oleh warga masyarakat di RT.02/ RW. 04 desa Teros Kecamatan Labuhan Haji. Pelaksanakan pengabdian tentang sosialisasi dan pembagian masker gratis sebagai upaya Preventif/ pencegahan penyebaran virus covid-19 di desa teros kecamatan Labuhan haji tersebut disambut antusias oleh warga masyarakat Desa Teros khususnya RT 02/ RW.04 karena dalam sosialisasi dari rumah ke rumah tersebut dirasakan lebih efektif karena untuk mencegah terjadinya kerumunan sehingga dapat memutus penyebaran virus covid 19 di masyarakat.

Selain memberikan sosialisasi diikuti juga dengan pemberian masker gratis untuk selau digunakan oleh masyarakat ketika keluar rumah karena hal ini sudah menjadi kebiasaan yang diharuskan oleh pemerintah untuk selalu memakai masker. Hal ini dilihat ketika berada di tempat umum, seperti di pasar maka selalu saja ada razia masker oleh pemerintah terkait. Dengan fenomena tersebut maka masyarakat terutama warga masyarakat RT.02/ RW.03 merasa sangat terbantu dalam hal pembagian masker gratis. Yang semula mereka cuekterhadap penyebaran virus covid 19.

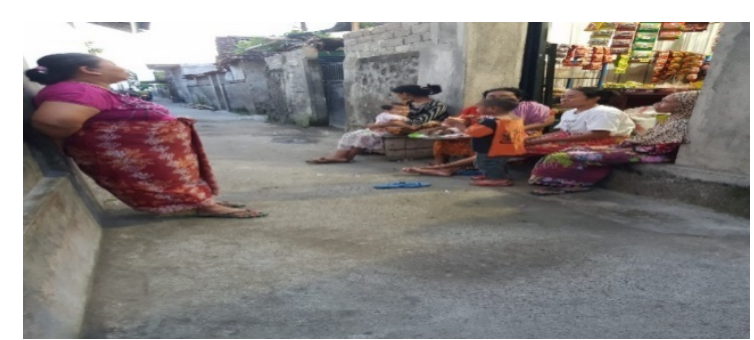

Gambar 2.Kondisi masyarakat desa Teros yang tidak memakai masker.

Kondisi yang terjadi di lokasi pengabdian bahwa banyak masyarakat yang tidak memakai masker pada saat mereka beraktifitas di luar rumah, maka dari itu yang menjadi tujuan dari pengabdian ini yaitu memberikan pengetahuan dan pemahaman terhadap pentingnya phsicial distancing dilakukan di kalangan masyarakat di RT.02 / RW. 04. Karena virus corona atau yang biasa disebut dengan virus covid 19 menyerang system pernapasan dan virus ini mengakibatkan penderitanya mengalami sesak nafas, pneumonia akut hingga mengalami kematian.

Virus ini bisa menyerang siapa saja seperti lansia (golongan usia anjut), orang dewasa, anak-anak dan bayi termasuk juga ibu hamil dan menyusui. Berdasarkan hali ini dirasa sangat penting untuk melakukan sosialisasi terhadap masyarakat sehingga menjadi sadar akan pentingnya pengamanan diri atauproteksi terhadap virus covid 19 karena penyebaran virus covid 19 ini dari hari kehari semakain bertambah jumlah pasien positif covid 19 bahkan di kota-kota lain di Indonesia secara umum sudah memberlakuakn PSBB atau pembatasan skala besar atau ada juga yang istilah di lock down atau ditutup sementara (Handayani, 2020). Dan fenomena yang terjadi secara umum di Lombok Timur sendiri sudah berubah menjadi zona merah yang semula zona hijau. Maka dari itu ini adalah tanggung jawab bersama dalam memutus penyebaran covid 19 atau virus corona dengan memberikan pemahaman kepada masyarakat untuk selalu jaga jarak atau phsicial distancing dan selalu menggunakan masker.

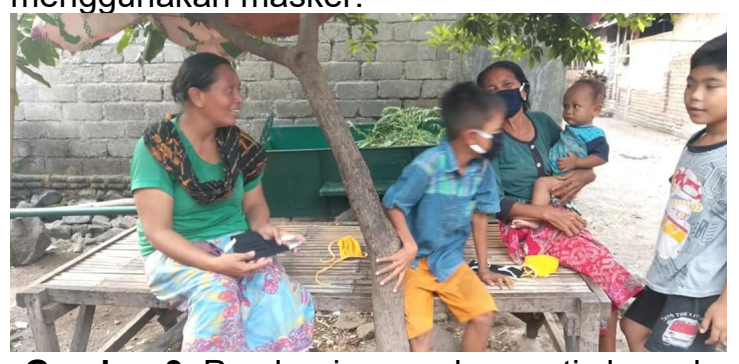

Gambar 3. Pembagian masker gratis kepada anak-anak 
Disamping itu juga pemberian masker gratis untuk ibu rumah tangga maupun anaanak. Sehingga apabila mereka keluar berkumpul maupun bermain bisa memproteksi diri sendiri dengan penggunaan masker untuk meminimalisir kontak dengan virus.

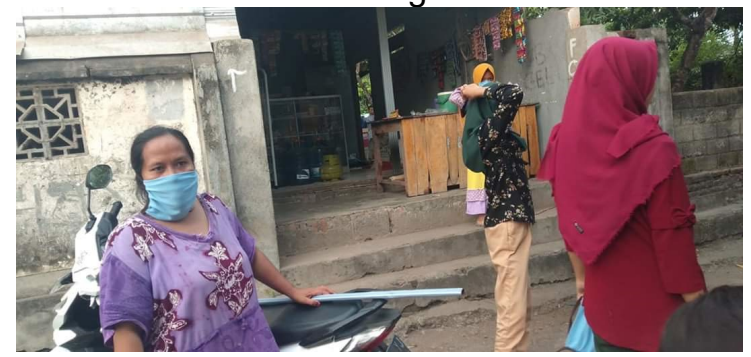

Gambar 4. Pemberian masker gratis kepada ibu rumah tangga

Tidak ketinggalan juga sosialisasi dan pemberian masker gratis terfokus pada ibu rumah tangga yang masih belum percaya terhadap virus corona sehingga dari rumah kerumah di laksanakan sosialisasi untuk memberikan kesadaran betapa berbahayanya virus corona tersebut maka dengan penggunakan masker dan pentingnya physical distancing atau jaga jarak, ibu rumah tangga bisa lebih memproteksi diri, keluarga dan masyarakat sekitar. Karena untuk lebih menekan penyebaran virus corona harus dimulai dari keluarga dulu supaya lebih aware terhadap bahaya virus corona.

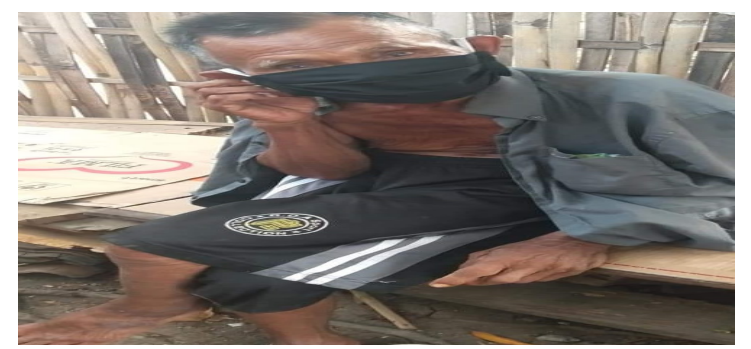

Gambar 5. Pemberian masker gratis kepada lansia

Dengan dilaksanakan kegiatan pengabdian tersebut di RT 02/RW 04 tersebut diharapkan untuk kedepannya masyarakat dapat menjadikan kebiasaan baru untuk selalu memakai masker dan menjaga jarak untuk mencegah penularan virus covid 19. Dan dengan pembagian masker gratis dikalangan, ibu rumah tangga, lansia dan anak-anak, di RT 02/RW 03 merasa terbantu dan mereka menyambut sangat antusias dengan adanya pembagian masker gratis tersebut.

\section{SIMPULAN DAN SARAN Simpulan}

Dari pelaksanaan kegiatan pengabdian tentang sosialisasi dan Pembagian Masker Gratis sebagai Upaya Preventif/ Pencegahan Penyebaran Virus Covid-19 Di Desa Teros Kecamatan Labuhan Haji. setelah diberikan pengetahuan dan pemahaman terhadap pandemic tersebut masyaraka sudah mulai paham dan aware terhadap bahaya dari covid 19. Dengan keterbukaan masyarakat yang ada di RT.02/RT.04 kegiatan pengabdian tersebut dapat berjalan lancar dan warga masyarakat dapat menerima segala anjuran yang diberikan agar dapat menjaga kesehatan dan keluarga bahkan masyarakat sekitarnya untuk selalu menjaga jarak dan untuk sementara waktu tidak melakukan kegiatan dengan berkumpul dengan masyarakat lainnya. Dengan pembagian masker gratis tersebut kami disambut antusias dari warga masyarakat karena dengan diberikannya sosialisasi maka warga masyarakat paham akan bahaya dari virus covid 19 dilanjutkan dengan pemberian masker gratis untuk dipergunakan apabila ke warga masyarakat berpergian atau ke luar rumah.

\section{Saran}

Diharapkan masyarakat lebih sadar akan pentingnya kesehatan dengan selau menerapkan phsicial distancing atau jaga jarak dan selau menggunakan masker ketika berpergian serta menggunakan handsanitaizer ketika sudah melaksanakan kontak dengan warga masyarakat lainnya, sebagai salah satu proteksi atau perlindungan diri dari virus covid 19.

\section{DAFTAR RUJUKAN}

Handayani, D. (2020) 'Penyakit Virus Corona 2019', Jurnal Respirologi Indonesia.

Muhyiddin (2020) 'New Normal dan Perencanaan Pembangunan Indonesia', The Indonesia Journal of Development Planning.

Parwanto, E. (2021) 'Virus Corona (SARS-CoV2) penyebab COVID-19 kini telah bermutasi', Jurnal Biomedika dan Kesehatan. doi: 10.18051/jbiomedkes.2021.v4.47-49.

Zahrotunnimah, Z. (2020) 'Langkah Taktis Pemerintah Daerah Dalam Pencegahan Penyebaran Virus Corona Covid-19 di Indonesia', SALAM: Jurnal Sosial dan Budaya Syar-i. doi: 10.15408/sjsbs.v7i3.15103. 